vary. As to rooms in the students' quarters, there is no difficulty ; board and lodging can be got en pension for 6 francs per diem and upwards, though it might be more advisable to take a room in one of the numerous hotels, and feed at a restaurant, which is cheaper. Should give him what information I can if he will write direct to the above address.

Dr. HARRY GReY (San Remo) writes: In answer to "M.D.," unless he wishes to take a course on some special subject, as, for example, bacteriology, it is quite unnecessary to make, previously, arrangements to join clinics. For surgical work, skin diseases, eye, etc., one can find in paris clinics at every hour of the day. There are absolutely no fees, not even for the lectures, and except for necropsies (medico-legal) at the Morgue, for which one must have a card. No enrolment is necesthe Morgue, for which one must have a card. This ird is obtained at the Secrétariat de l'Ecole de Médecine on pry. This card is obtained at the Secretariat de l'Ecole de Medecine on ittend lectures he should of course avoid vacations. The next is the first half of April. I think. The only thing that should be done before jeaving home is to obtain introductions to professors of the subjects he intends to study. As regards rooms in the Quartier Latin he can live fir 30 francs a inonth, and comfortably for 60. On arrival a speedy a. -quaintance with one of the old students will help him to decide on be happy to give him the benefit of my own experience.

TREATMENT OF DANDRUFF.

IN reply to the question asked by, "W. D. B." in the BRITISH MEDICAL this condition will be found quite simple and perfectly effectual: "lis condition will be found quite simple and perfectly effectual: (irouilla), or in detault of this with spiritus saponis alk. (Hebra). (Youilla), or in detault of this with spiritus saponis alk. (Hebra); then rild in collapsible tubes convenient for use, an element of importance cold in collapsible tubes convenient for use, an element of importance wheaking. once a weck is sufficient to keep the scalp clean, although at first if the scurf is copious it may be sbampooed and dressed every day. if patches of seborrhœal eczema exist on the scalp, on the brow. or on pusol to an ounco of vaseline, and gently rub it in.

NOTES, LETTERS, Dte.

In RATUM. - In the report of the Border Counties Branch in the BRITISH MEDICAT. TOURNAT, of February 27 th, p. 528 , in Dr. Somerville's remarks,
socond column, fifth line from top, "cryptolites" should read graptolites.

\section{A Disclaimer.}

D :. ALBERT WILSON writes to disclaim any knowledge of how the Daily a rccent meeting of the Clinical society.

OYSTERS AND TYPHOID FEVER.

Mn G. H. BAXTER (Hutton, Essex) writes: With reference to Mr. HenHiker Heaton's statement in the House of Commons as to the only inrance of enteric fever in epidemic form arising in the United Kingdom
finm oysters being traced to the eating of Dutch oysters, I beg to state fon oysters being traced to the eating of Dutch oysters, I beg to state That the nnly case of epjdemic known to me is the outbreak at Stirling. This outbreak was at first attributed to the consumption of Dutch that it, was really due to a burst drain in the Town Hall. Query: May that it, was really due to a burst drain in the Town Hall. Query : May
int. nther rases that have been reported as oyster poisoning be of a like nature to the above?

Lincoln Medical Protection Fund

Dr. W. A. CARLINe (Lincoln) writes : Will you kindly publish the accompanying atatement of accounts of the above fund? Since the last list published $\mathrm{I}$ have received the following subscription

T. M. King, M.A., 4, Mortlake Road, Kew … ‥ $6 \mathrm{r}$.

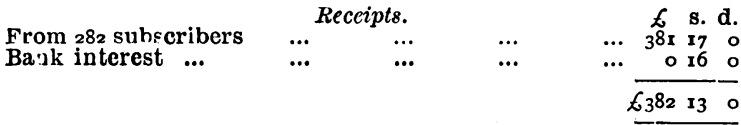

Payments.

$\begin{array}{lllll}\text { Printing, addressing, and postage of appeals (8,ooo) } & \ldots & 35 & 14 & 0\end{array}$

Printing rules and cards, and cosc of drugs for same...

$\begin{array}{llllrl}\text { Printing rules and cards, and cosc of drugs for same } \ldots & 7 & 5 & 2 \\ \text { Rents and taxes for same } & \ldots & \ldots & \ldots & \text { I } & \text { r }\end{array}$

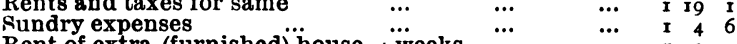

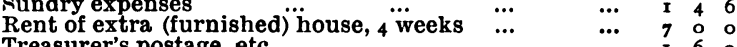

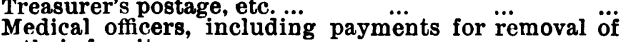

their furniture:

$$
\begin{aligned}
& \text { Mr. Johnston } \\
& \text { Mr. Whitwell }
\end{aligned}
$$

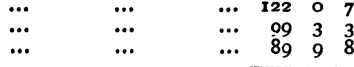

$$
\begin{aligned}
& £ 382 \times 3 \circ
\end{aligned}
$$

(Signed) Geo. Mitchinson, ?

Charles BroOK, $\}$ Trustees.

W. A. CARLINe, Hon. Treasurer.

Tire Influence on the Action of the Auricle of Variations in D. ITS CAPACITY.

. Since the publication of My fo:mer communication under the above heading in the BRITISH
MíDICAL JoURNAL of January $23 \mathrm{rd}, \mathrm{my}$ attention has been directed to a very instructive paper published in the Journal of Anatomy and Physiolngy, vol. Xxvi, by Mr. Robert H. Woods, entitled, "A few applications of a physical theorem to membranes in the human body in a state of tension." This paper was read before the Royal Academy of Medicine mathematically not only that the blood pressure inside a contracting cardiac chamber varies inversely as the radius of the chamber, but that if the increasing thickness of the contracting walls be also taken into consideration, the blo

In my Paris thesis ( Le rôle de l'oreillette gauche notamment dans le rétrécissement mitral, July, 18,6$)$ I gave the expression $P=2 \frac{t . e}{r}$ where $P$ $=$ the blood pressure sustained by each unit of surface of the cardiac wall; $t=$ the muscular tension per unit of sectiac at and the chamber at the time.

Now $e$ varies as $\frac{T}{r^{2}}$ therefore $P$ varies as $\frac{T}{r^{3}}$. The auricle consequently on contracting and reducing its diameter by one half would be able to increase the intra-auricular blood pressure eightfold, supposing constant while they shorten. Such an intra-auricular blood pressure would equal or almost equal the minimum pressure the ventricle could would equal or almost equal the minimum pressure the ventricle could generate before it forced open the aortic valves, after which the jntra-
ventricular pressure cannot, of course, appreciably increase. The intraauricular pressure would, however, continue to increase rapidly as the chamber continued to decrease in size. and might easily exceed the chamber continued to decrease in size, and might ea

It is quite true that instead of thinking that regurgitation from the ventricle to the auricle is only prevented by the auriculo-ventricular valves, we should admit a second factor of almost equal importance, and that is the contracting auricle. It is the auricle which largely prevents that is the contracting auricle. It is the auricle which largely prevents regurgitation from the ventricle during the first phase of the contrac-
tion of the latter, for the auriculo-ventricular valves do not shut when tion of the latter, for the auriculo-ventricular valves do not shut when
the ventricle contracts. They appear to shut about the time that the auricle relaxes and ceases to support them, a time closely coinciding auricle relaxes and ceases to support them, a tim

In mitral stenosis cases the prolonged contraction of the hypertrophied auricle defends the mitral orifice till still later in the ventricu prevent regurgitation from the ventricle, though the mitral orifice be prevent regurgitation
very incompetent.

The Treatment of Malignant Disease by the Injection of the TOXINS OF ERYSIPELAS.

DR. HERBERT SNOW (London, W.) writes: May I point out, in the first place, that "shrinkage and apparent disappearance of the tumour" are always put forth as to the credentials of every new remedy applied in the same mode-that is, by acupuncture in one form or anotherfrom time immemorial. Second , that orten-repeat it does prot in are the really essential agencies in efrecting that result; is does not in all. Thirdly, that life is never prolonged a single day, and may be materially shortened; death, resulting as usual in malignant disease from the metastases and blood infection much more than from the effects of the local lesion. As examples in my own experience I would cite galvano-puncture in various forms, carbolic acid, methylene blue. blood and serum. and becomes less tense, this shrinkage being subsequently enhanced by cicatricial contracticn. The idea that erysipelas is antagonistic to sarcoma or carcinoma was first announced from the States about eighteen years ago. Nothing lending it the smallest countenance has ever been noticed at the Cancer Hospital.

\section{TREATMENT OF HICCOUGH.}

A MEMBER writes: In Dr. Cooper's severe case of typhoid in which antitoxin was successfully employed, reported in the BRITISH MEDicaL JOURNAL of February 27 th, I note that hiccough proved very refractory. May I suggest that the inhalation of oxygen be tried where this sym: ptom proves troublesome? I have once seen great relief to trying hiccough procured by its use.

" Every Parent Read This"

Such is the headline of a red-lettered leaflet of the Norking and District Anti-compulsory Vaccination League. Some figures are given as to Gloucester, but the case mortality of the unvaccinal ed as compared with credit their readers with much intelligence.

The Dorsal Test for Pericardial Effusion.

DR. WM. EWART (Curzon Street, W.) writes: A misprint, which might possibly mislead and which your kindness mav yllow me to correct. occurs in my letter on this subject in the BRITISH MEDICAL JOURNAL of Feb. 27th, p. 558, In the sentence, "a definite quadililateral patch of lateral dulness," etc., "absolute" should be read instead of "fateral." The patch, extending on either side of the eleventh and twelfth dorsa spines, is essentially median in position, though it is decidedly jarger and duller on the left than on the right. Again, in the sentence "(3) ness" should be understood.

The Battle of the Clubs in the United States.

The physicians and surgeons of Santa Clare County, California, have resolved that "rendering professional services at a stipulated fee per capita per annum is derogatory to the dignity of the medical profession," and henceforth will not "enter into any contract or agreement, or implied, to render medical or surgical services to any lodge, society, members of these bodies for less compensation than the general public pay for similar services. 